\title{
GLISSONIAN RICKETS
}

\author{
BY
}

\author{
C. E. KELLETT, M.D., M.R.C.P.
}

(From the University of Durham College of Medicine and the Babies'

Hospital, Newcastle-on-Tyne.)

At the beginning of the seventeenth century there appeared a new disease of childhood, which the common people called 'The Rickets,' but which achieved such notoriety that for many years it was also known as the 'English Disease.' So far as I know, the factors underlying the appearance of this condition in epidemic form have never been adequately determined. Creighton has scarcely referred at all to this malady in his ' History of Epidemics in England.' Although our understanding of this condition has advanced so greatly during the past few years, this omission has not been rectified and yet contributions such as those of Park and Eliot suggest that our understanding of the etiology of this condition is greater than that of any other condition in childhood. In this paper I have endeavoured briefly to determine some of the factors which determined the appearance in epidemic proportions of this condition.

Apart from the work of Glisson and his colleagues, medical writers have not added much to our knowledge of rickets at the period of its onset. Economists from the time of Graunt to the present day have collected and analyzed data of such value that a paper of this nature is inevitably greatly indebted to the results of their labours. In this instance acknowledgments are due more particularly to those of Eden, Rogers, Schanz, Hasbach, Cunningham, Ashley, Lipson, Leonard, Friis, Power and Postan, James and Clark.

The novelty of this malady, its place and time of origin have all been clearly indicated by Glisson and acknowledged by such subsequent authorities as van Swieten.

He, who will accurately contemplate the signs of this effect, as in their due places they shall be propounded, may most easily perswade himself, That this is absolutely a new disease, and never described by any of the Ancient or Modern Writers in their practical Books which are extant at this day of the Diseases of Infants. But this Disease became first known as neer as we could gather from the Relation of others after sedulous enquiry, about thirty years since in the Counties of Dorset and Somerset, lying in the Western parts of England, since which time the observation of it hath been derived unto other places, as London, Oxford, Cambridge and almost all the Southern and Western parts of the Kingdom : in the Northern Counties this effect is very rarely seen, and scarcely yet made known amongst the vulgar sort of people. (Glisson.)

Now the spread of this condition throughout England is not at first sight as remarkable as its apparently rural origin; nor might it be considered momentous since present day statistics reveal a distribution equally wide- 
spread. Glisson while aware of the milder form, now so prevalent, was evidently concerned with the spread of the advanced and florid type of rickets. The distinguishing of such cases of florid and advanced rickets with the epithet glissonian is possibly unjustifiable; nevertheless throughout this paper I shall continue to do so, for this will serve to emphasize certain aspects of the history of this condition which have hitherto been neglected. In the first place, this was the new disease for which Glisson so emphatically claims a priority of description; and in addition, despite the lack of modern diagnostic facilities which play such a rôle in the present recognition of rickets, he was prepared to believe that the first rudiments of the disease were far more widespread than was commonly believed. Furthermore this epidemic of glissonian rickets was of relatively short duration, and would appear never to have so gravely involved the continent, with the not unusual result that the condition continued to arouse interest abroad long after its subsidence had rendered it of little account in England.

Glisson's own classical description of the disease is largely based on post-mortem material, and yet so soon as in 1690 Havers ' confesses' that he had never ' had the opportunity to examine the bones of any rickety children.' By 1700 the condition had become so mild that English paediatricians appear to have taken little interest in it; Harris barely refers to it; Armstrong states that it

cannot be reckoned amongst the fatal diseases of infants. Indeed the air where I live, being so very dry, I have seldom met with it unless amongst nurse children that have been sent out of London with it upon them.

The stress and urgency apparent in Glisson and, to a less extent in Primerosius and Mayow, have gone, and in the subsequent eighteenth century descriptions such as those of Underwood or Buchanan, there is a familiar academic ring.

Abroad, however, if the bibliography of de Ploucquet or the history of Trnka be not misleading, this 'English Disease' was still considered of moment. It is significant that even a lay traveller, such as Don Gonzales who returned in $\mathbf{1 7 3 0}$ from a tour of England and Scotland not unlike that completed by Defoe three years before, should have added to his account that the English were ' very subject to some particular diseases, especially the rickets, the scurvy and the consumption,' whereas Defoe mentions only the ague in Essex and the marital arrangements it involved. At the beginning of the nineteenth century Bateman recorded a diminishing mortality from rickets* and thirty-six years later Merei made the legitimate complaint that ' comprehensive systematic works on diseases of children, lately published, contain no information on this disorder.' But rickets which was rare then in its glissonian form, possibly as rare as it is again now, which was moreover shortly afterwards to become prominent once more for a period, was even then, as now, in its ' first impression and rudiments' actually exceedingly prevalent.

* In 1649 the deaths from rickets in London amounted to 190; in 1650 to 260; in 1651 to 329; in 1660 to 521 ; but in 1700 these had decreased to 393 ; in 1750 to 21 ; and in 1799 the deaths from ' evil and rickets' together did not exceed 7, 
Sir William Fordyce, a contemporary of Bateman's, whose general theme is what he calls 'the hectic fever of children' asserts

that there must be very near 20,000 children in London, and Westminster and the suburbs (if this be questioned, examine the public charity schools and workhouses, the purlieus of St. Giles's and Drury Lane, and satisfy yourselves) ill at this moment of the hectic fever, attended with tun-bellies, swelled wrists and ancles, or crooked limbs, owing to the impure air which they breathe, the improper food on which they live, or the improper manner in which their fond parents or nurses rear them up.

This ' hectic fever' is, as Creighton points out, clearly the condition we call rickets; it is possibly significant, therefore, that Sir William Fordyce, though elsewhere he uses the epithet ' ricketty' freely, did not so here employ it or so regard it, but would in effect have appeared to have observed this very distinction.

Such cases of glissonian rickets are now sporadic and uncommon. In November, 1928, however, twin children, a boy and a girl, aged 2 years and 10 months, were admitted to the Hospital for Sick Children, Great Ormond Street, suffering from rickets, ' the signs and symptoms of which were most outrageous' and unforgettable. It is to them this paper owes its inception. In the little girl especially lay mirrored Glisson's own vivid description.

\section{Economic factors.}

Under the Tudors the population of England, which had apparently long remained stationary, began to increase. This rate of increase was, as Pearl has shown, to obey closely the equations he has laid down, equations which appear to apply to all growths of population, whether they be bacteria or men. At the same time, and possibly in relation to this, other fundamental changes began to take place in England. For generations she had supplied the Flemish weavers with wool, and so indirectly clothed most of Europe. For a variety of reasons, dependant both on the climate and on the relative peace within her borders, wool production had become almost her monopoly. The average production of wool was in the region of 30,000 sacks per annum. But it appeared obviously a sound policy that the wool of the country should be worked up in England, and the languishing cloth trade revived.

Fig. 1 and 2 have been constructed from the figures obtained by Schanz, and quite recently by Power and Postan from the Customs Accounts preserved in the Public Record Office. They are of considerable significance and strikingly demonstrate the success of the policy initiated by Edward III. In both these diagrams, the black columns represent the exports of wool in sacks, and the white of cloths in units of 10 cloths. The taller column in every case is placed behind the shorter one. The upper black columns represent the total wool exported in sacks, based on the rough, but generally accepted, assumption that 4 cloths were made from a sack of wool.

For the other periods there are no such figures available, but so far as I can determine this process reached its peak about 1600 . At the beginning of this period the exports from London alone' averaged 130,000 cloths a year. The destruction of the Hanseatic trade, moreover, enabled the northern merchants to revive their own; in 1616 Newcastle exported 5,267 $\frac{1}{4}$ short cloths; in 1614 Hull exported 18,608. If at this time, with the exception of Ipswich, the exports from the Eastern and South Eastern ports were almost negligible, the South Western ports exported nearly 20,000 cloths a year. In 1613, Coke, the Attorney-General, stated that the Cloth Trade represented 90 per cent. of the total export trade of England. Nevertheless, 
the position of the trade was already precarious and the country drifted towards the civil war in which this unique monopoly that England held was finally lost: while in 1618 began the Thirty Years' War in Germany, which was to bring such misery to her people, one of the most important of England's customers, that in
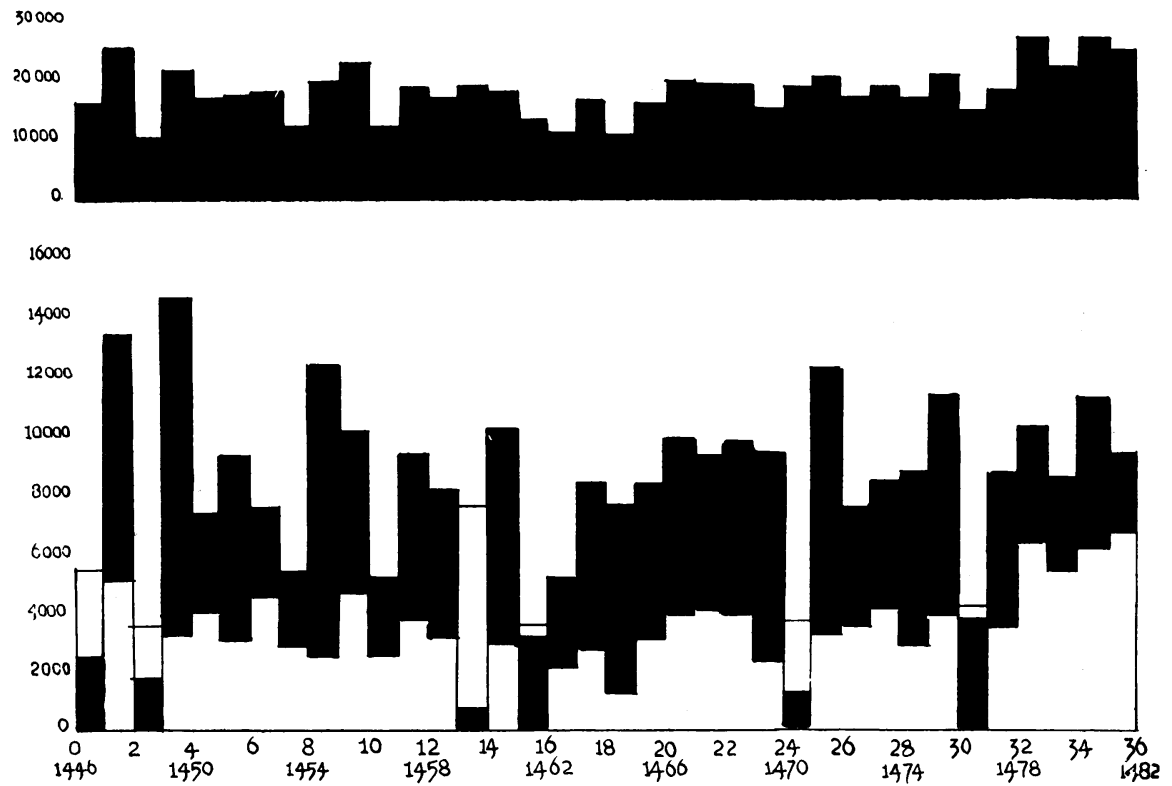

FIG. 1.
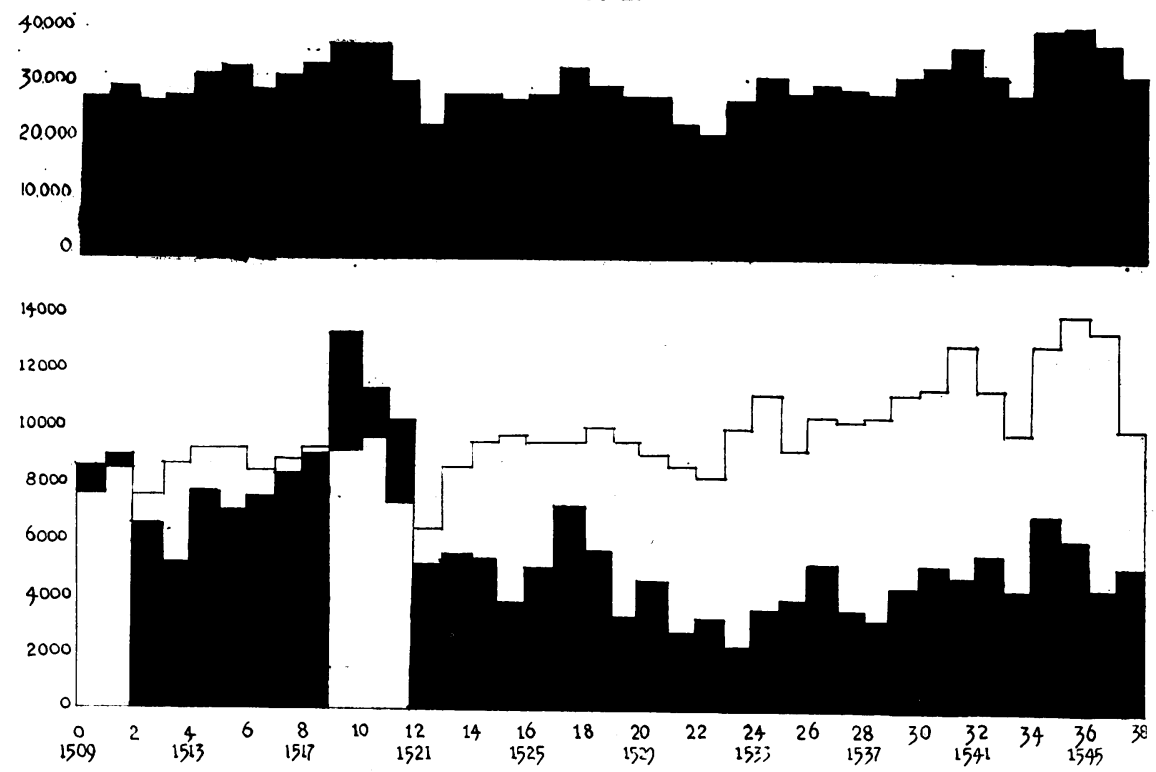

Fig. 2.

1648, after the Treaty of Westphalia at Lutzen, her population, which had previously been estimated at twenty millions was found to have been reduced to about six millions (Buck). Eight years later Bradshaw remarks that 'the extent to which uur trade with Germany has diminished will be obvious when we realise that, when 
the Merchant Adventurers first came to Hamburg, they sold from 80,000 to 100,000 cloths, and now their total never exceeds 20,000.' The civil war was in England, and already the cloth makers were beginning to emigrate back to the countries from which members of their craft had come some three hundred years before. The woollen trade gradually declined from its paramount and unique position.

Now it was the rise of this single enormous industry that gave rise to changes in the whole structure of English society, changes themselves responsible for the appearance of glissonian rickets in epidemic form. In the first place it led, particularly in the west country, both directly and indirectly to the formation of a large wage-earning class. The population of England at the beginning of the seventeenth century must still have been under 5,000,000; but it is estimated that of these about $1,000,000$ were dependant on the cloth trade. The rise of this trade indirectly increased the wage-earning class by precipitating the so-called agrarian revolution.

The appearance of a large wage-earning class in England at this period, while probably inevitable, was unfortunate because of the marked depreciation in the value of money that occurred over this period. This was in part due to the debasement of the coinage, and again in part was due to the discovery of America and new vast sources of silver and gold. A whole series of further factors led to a marked increase in the price of foodstuffs, but there was no concurrent increase in the price of wages; indeed special efforts were made through the machinery of wage assessments to keep them down.

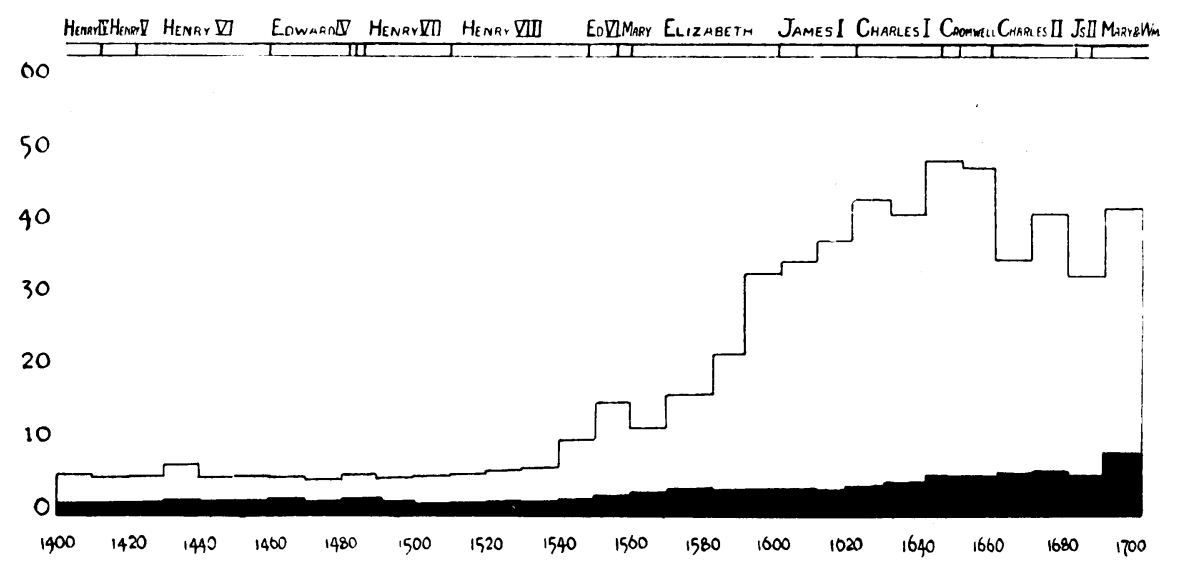

Fig. 3.

In this chart (Fig. 3) the decennial average price of wheat per quarter from 1400 A.D. to 1700 A.D. is given by the white column in shillings, while the black column represents the average weekly wage earnings of a labourer, again in shillings. It is apparent that the discrepancy between the two reached its maximum in the period from 1620-1660, the period in which glissonian rickets became epidemic. But this chart does not reveal the whole picture. During this period not only was employment in the wool industry uncertain, and stoppages frequent, particularly during the civil war, but there were, as shown in the following chart, again constructed from Thorold Rogers' figures, the most remarkable fluctuations in the 
price of wheat, which were in no way countered by similar fluctuations in wages; both of which are indicated in the preceding chart.

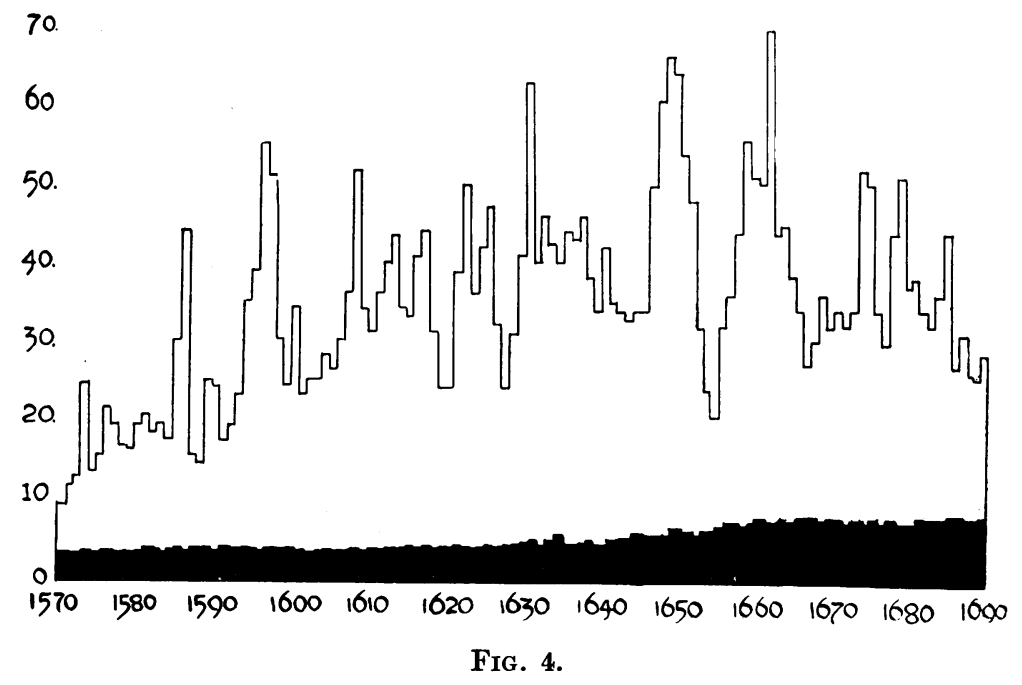

Towards the end of the seventeenth century, when things for the wage earner were beginning to improve, Gregory King calculated that the population of the kingdom was in the region of $5 \frac{1}{2}$ million people; he estimated that whereas $2,675,520$ people were able to save money and so increase the wealth of the kingdom, no less than 2,823,000, comprising labourers, cottagers, seamen and soldiers, decreased the wealth of the kingdom, earning less than their requirements. This meant as Rogers points out, and his figures in the main confirm King's, that 'more than half the families in the country were absolutely short of the bare necessaries of life.'

This discrepancy between the wages and prices meant, furthermore-and this is a most important factor in the enormous infant mortality of this period - that if a wage earner was to marry and have children, his wife must, as a rule, become a wage earner too. For in those days the whole life of the infant must have been governed by the activities of its mother, or else of its elder sisters and brothers.

Utterly deplorable as were the conditions that Clark has revealed, under which the wife of the agricultural labourer brought up her children-the few that could hope to survive-ideal conditions for the production of glissonian rickets are to be found not with them but amongst those engaged in the great textile industry. It is almost certain that of the more than a million people - that is probably over a quarter of the population-who were engaged exclusively in the clothing trade, women and children were in the ratio of about eight to one man. Spinning was altogther their monopoly, and their children were taught to spin from their earliest years, and to assist in other ways; those who were four to eight years old could earn a penny a day for quilling, and from eight to twelve twopence to fourpence for spinning. But this must have been a maximum; as a rule their parent could earn no more. The work was all done at home, in the workman's poor cottage. The hours were long: a seventeenth century writer, quoted by Lipson states ' that 
a poor weaver sits at his loom from four in the morning till eight, nine, ten at night.'

Cold winters appear to have been rather the rule during the first half of the seventeenth century. Though this was a period well before instrumental recordings, references from contemporary literature, collected by Lowe and, more recently, by Sir Richard Gregory show that the Thames was frozen in $1607,1608,1609,1620,1622$ and 1649 . Wet summers, too, it would appear were not uncommon towards the middle of this century.

There is, however, other evidence that suggests that this factor, though it may have operated by tending to make the wool-workers keep indoors, was not itself directly responsible for rickets. Thorold Rogers has pointed out that much of the salt consumed in England, largely it is true imported from Guienne, was produced by solar evaporation, so that 'the price of salt is a rough measure of the solar heat of the previous year.' The list of prices he gives for this period are not such as to suggest that Western Europe suffered from any gross impairment in sunshine at this time.

The hypothesis here advanced, which relates the seventeenth century epidemic of rickets to the factors operative in the clothing industry in England at this period, receives very considerable further support from Glisson's own description of the geographical incidence of the malady.

Complete ulnage returns appear to exist only for a period towards the end of the fifteenth century; from these Heaton has constructed a map showing the distribution of cloth production in England for that period. There were three main centres: of these the most important was the West of England-Gloucestershire, Wiltshire, Somerset, Oxford, Berkshire, Hants, Devon, Cornwall and Dorset, producing 18,884 cloths, or about 48 per cent. of the total production; East Anglia came second-Norfolk, Suffolk, Essex, Hertford and Middlesex together making 9,878 cloths or about 25 per cent. of the total production, and Yorkshire came third with a production of 4,972 cloths.

During the next hundred years this supremacy of the western counties was more than maintained. The great bulk of the cloth they made went to the Netherlands and London became their main outport, with exports almost three times as great as the rest of the ports of England put together. The south western ports were, however, able to monopolize the trade to France and Spain in the cloths of their own counties, while 'Newcastle and Hull (York included) could lay claims to the trade in coarse Northern cloth to the Baltic, and even to the low countries they were able to carry no small quantities of their own cloth.' (Friis.)

Not only had the western counties become by far the most important cloth making district in England; not only had they at the same time become more susceptible to the fluctuations in trade and to the difficulties in transport which arose particularly in the Civil War; but the whole organisation of their industry differed fundamentally from that of the northern cloth industry. Those engaged in the industry in the west and east country were far less able to withstand these changes than those in the north. In the 
west the industry was essentially a capitalist one. The workmen, particularly the spinners, were very poorly paid. 'In the seventeenth and eighteenth centuries England's greatest industry rested on the basis of sweated labour ' (Lipson). This too was true for the East Anglian industry. In a diversity of ways this affected the wage earners' mode of life.

Eden's description, though written over a hundred years later may, I think, be shown to apply, in the main, to the period under review.

It must strike everyone who has at all investigated the subject of diet, that there is not only a remarkable difference in the proportion of earnings appropriated to the purchase of subsistence of labourers in the North and South of England, but that their mode of preparing their food is no less dissimilar. In the South of England the poorest labourers are habituated to the unvarying meal of dry bread and cheese from week's end to week's end; and in those families whose finances do not allow them the indulgence of malt liquor, the deleterious product of China, constitutes their main beverage .... In the North of England, Scotland and Wales, the poorest labourers, however, regale themselves with a variety of dishes unknown in the South. To begin with : Hasty Pudding, which is made of oatmeal, water and salt, about $13 \mathrm{oz}$. of meal to a quart of water, which is sufficient for a meal for two labourers. It is eaten with a little milk or beer poured upon it, or with a little cold butter put in the middle, or with a little treacle ....

And so through a whole variety of dishes, in which as opposed to the South, cereals other than wheat figure prominently, and milk and butter. In the North the general drink of the labouring classes is still ' whey or milk, or rather milk and water' (Eden).

The Southerner bought all the clothes he wore, and most commonly at second hand, but ' in the North on the contrary, almost every article of dress worn by the farmers, mechanics and labourers is manufactured at home.'

In view of Mellanby's work on the rôle of different cereals in the production of rickets under experimental conditions, it is interesting to note that cereals other than wheat figure largely in this account of the North countryman's diet. The composition of bread at that time is also of some importance. Gradually wheaten bread was to become the sole bread eaten in England. This change originated in the South and the East, probably because in these parts alone was capital available for the necessary improvements. Ashley, who has discussed much of the relevant evidence, suggests that in 1696 only 38 per cent. of the bread was wheaten, in 1764 some 64 per cent., in 179595 per cent. if not 100 per cent. Even were it possible that. wheat were available for the wage earner, the enormous rise in prices already alluded to was soon to take it beyond his reach in the period with which we are concerned, during which glissonian rickets was common. Early in the seventeenth century when rickets first attracted attention, the price of wheat had risen from $16 \mathrm{~s}$. to $45 \mathrm{~s}$. a quarter.

\section{Current conditions in clothing industry.}

With these factors in mind, many of which accord well with Glisson's own evidence, it has also seemed worth while to report briefly the conditions under which the two cases of glissonian rickets I have mentioned arose. 
It is perhaps no more than a coincidence, but nevertheless interesting, that they should constitute one of the rare survivals to our own day of the conditions in vogue in Glisson's time.

For though in England, especially, the factory system was relatively rapidly to supplant the home work system of the Master Clothier of the West of England and the spinning jenny, the spinster, certain survivals of this practice there have been, and that especially in certain branches of the clothing industry. Of these, perhaps, the most interesting and the best known are the body of journeymen tailors who work for the relatively few exclusive West End tailors in London, members of the A.L.M.T., and still exclusively handicraft tailors. More than 5,000 tailors work for these firms, and of these over 95 per cent. either in their own homes or in 'sittings.' The majority of them live in Soho and are often referred to as the 'Soho Tailors.'

In the case of the family with which we are concerned laziness on the part of the father appears to have added to the difficulties of rearing the children. It was almost inevitable with them, as it must have been in so many cases in the seventeenth century, that they should be poorly nourished on cheap and starchy foods and kept indoors with their parents, who, in the winter at any rate, would have to be at work in the few daylight hours there were.

\section{Clinical summary.}

The twins were born at full term, and the delivery was normal. They were breast fed for the first year; then for six months given two additional feeds of bread and sugar boiled in half a pint of milk. After 18 months they had the same food as their parents, mostly bread and margarine, potatoes and gravy, with meat and fruit once a week. During this pregnancy, and while suckling the twins, which she did for 18 months, the mother lived on bread and margarine, tea and potatoes.

They lived in two fairly large rooms in a house in Soho, for which they paid a rental of 18/- a week; the bedroom in particular was very dirty and badly kept. The father, who is described as being lazy and dirty, was a tailor, who worked at home; the mother of the children lived with him, helped him, but was not married to him. On the average he earned 50/- a week which he handed over to her.

In November, 1928, these twins were admitted into the Hospital for Sick Children.

The x-ray photograph of the girl's wrist (Fig. 5), taken two months later, reveals some sign of improvement. It differs, however, in certain respects from those commonly encountered in ordinary rickets. The condition it reveals is so intense as to resemble that achieved under experimental conditions; there is little or no evidence of seasonal remissions, but rather of a prolonged and constant process, which has led to a striking shortening of the bone. It is this constancy of the process that has contributed towards the formation of a glissonian picture, a constancy which must apparently be related to their comparative incarceration, their relative isolation from seasonal change and sunshine.

\section{Comment.}

Should this be so, then the factors which have been enumerated in this paper explain not only the onset of glissonian rickets in the seventeenth 
century in epidemic form, but also some of the paradoxes inherent in Glisson's own description.

This was not primarily an urban disease, as has been suggested, for the factory system had barely begun to be evolved. It was one associated with

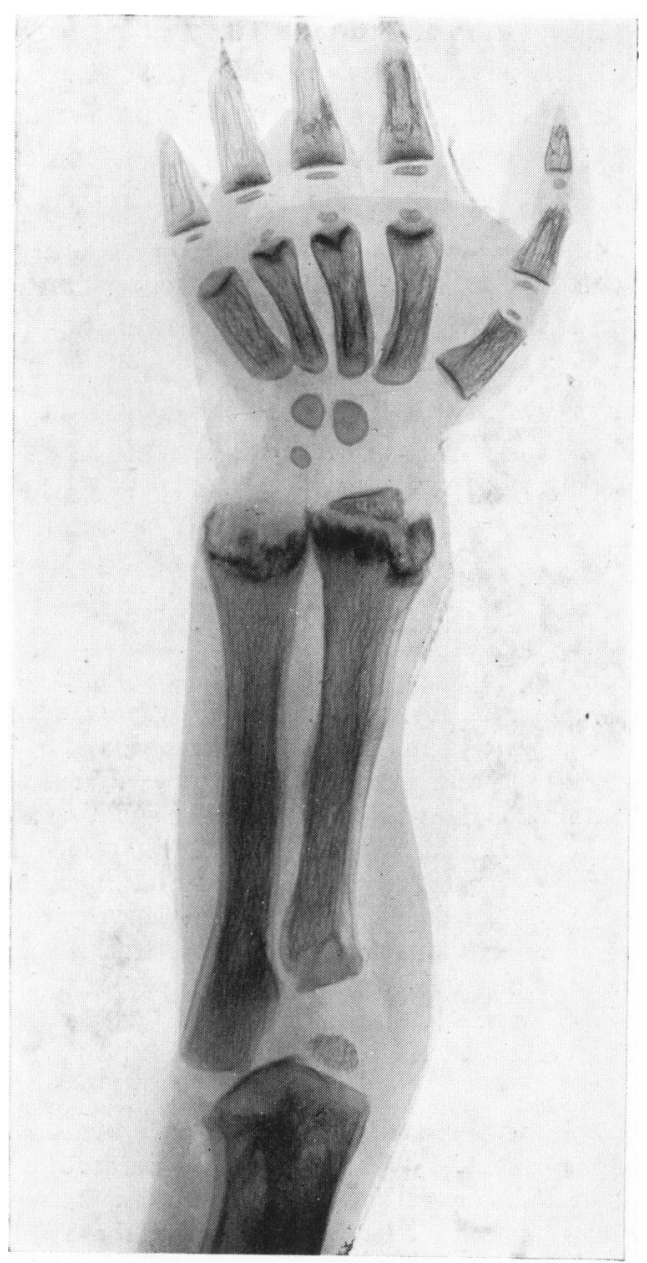

Fig. 5.

the rise of the great clothing industry in England, and dependant on the conditions in the people's own homes, the need that almost every member of the family should be engaged in work if destitution was to be avoided, and upon the fact that so great a proportion of the population in England 
had become of a necessity engaged in preparing and spinning the wool for this industry.

At that time there were very many poor in England, and the poor law was administered with almost unparalleled ferocity; but as Glisson emphasizes, it was not amongst them, the children of the workless and the vagabonds that rickets arose, but amongst the children of the industrious and relatively rich. In the North each family retained its independence, more or less, and owned a certain amount of land; there was ample reason for a proportion of their existence being spent out of doors; their diet was relatively varied. In the South and East of England an entirely different set of conditions prevailed. Under the system there prevalent, the workless lost much of their independence and, as Clarke points out, rather similar changes were taking place amongst the wives of the newly rich, their masters.

\section{Summary.}

An attempt has been made in this paper to show that the rickets which Glisson described may be considered to differ in certain respects, more particularly in its severity, from that commonly encountered at present, or from that which existed before his time. It was often fatal in its effects, and to begin with was epidemic, but only for a relatively short period. It is noteworthy that by the end of the eighteenth century little or no interest was being taken in the condition. This form of rickets has been termed glissonian.

Glissonian rickets is now a rare condition. However, sporadic examples do still occur, and two such cases are here mentioned. These two children had been fed on a rachitogenic diet, as had their mother while bearing and suckling them. In addition they had, so far as could be ascertained, spent almost all their life confined to one ill-lit room. This factor of virtual incarceration is of considerable importance in the production of glissonian rickets in that seasonal remissions are thereby prevented and the rachitic process is therefore constant and unremittent in its effects. Further analysis showed moreover that this factor was itself no more than an expression of economic stress and a certain definite economic structure.

In this paper it is shown briefly how this particular economic structure and these economic stresses arose in England, and reached their climax in Glisson's own time, and it is suggested that this is not a mere coincidence but that Glisson described a type of rickets to which his name may be rightly applied; a type which was once epidemic, but which now occurs rarely and in sporadic form.

It is a great pleasure to have this opportunity for thanking Dr. F. J. Poynton for his kindness, and his advice, and for allowing me to publish details of these two cases of rickets which were admitted under his care into the Hospital for Sick Children, Great Ormond Street, London. 


\section{BIBLIOGRAPHY.}

Armstrong, G., An Essay on the Diseases most fatal to Infants, London 1767, 96.

Ashley, W. J., Economic History, London, 1925.

Ashley, Sir W., The Bread of our Forefathers, Oxford, 1928, 8.

Bateman, T., Reports on the Diseases of London, London, 1819, 5.

Buchanan, W., Domestic Medicine, London, 1781, 610.

Buck, A. H., The Growth of Medicine, London and Newhaven, 1917, 427.

Clark, Alice, Working Life of Women in the Seventeenth Century, London, 1919.

Coke, Sir Edward, quoted by Friis, $\mathbf{A}$.

Creighton, C., History of Epidemics in England, Cambridge, 1894.

Cunningham, W., The Growth of English Industry and Commerce in Modern Times, II, pt. I, Cambridge, 1925.

Defoe, D., A Tour thro' the whole Island of Great Britain, London, 1927, I, 13.

Dobbs, S. P., The Clothing Workers of Great Britain, London, 1928.

Eden, F. M., The State of the Poor, London, 1928.

Fordyce, W., A New Enquiry, etc., London, 1773, 207.

Friis, A., Alderman Cockayne's Project and the Cloth Trade, Copenhagen and London, 1927.

Glisson, F., Bate, G., \& Regemorter, A., Treatise of the Rickets, London, 1681.

Don Gonzales, M., A collection of Voyages and Travels, London, 1747, I, 197.

Graunt, J., The Economic Writings of Sir William Petty, Cambridge, 1899, II, 458.

Gregory, Sir Richard, The Geographical Teacher, 1923-24, XII, 255.

Harris, W., De Morbis Acutis Infantum, second edition, London, 1705, 29.

Hasbach, W., A History of the English Agricultural Labourer, London, 1908.

Havers, C., Osteologia Nova, London, 1691, 155.

Heaton, H., The Yorkshire Woollen and Worsted Industries, Oxford, 1920.

James, Margaret, Social Problems and Policy during the Puritan Revolution, 16401660, London, 1930.

King, Gregory, Natural and Political Observations, London, 1910, 48.

Krzowitz, Trnka de, Historia Rachiditis, Vindobonae, 1787.

Leonard, E. M., Early History of English Poor Relief, Cambridge, 1900.

Lipson, E., History of the Woollen and Worsted Industries, London, 1921.

Lowe, E. J., Natural Phenomena and Chronology of the Seasons, London, 1870.

Mayow, John, Tract of the Disease Rachitis, Oxford, 1685.

Mellanby, E., Med. Res. Counc., Spec. Rep. Series No. 93, 1925.

Merei, A. A., On the Disorders of Infantile Development and Rickets, London, $1855,145$.

Park, E. A., \& Eliot, M., Dis. of Infancy and Childhood, Oxford Medical Publications, London, 1933, I, 216.

Pearl, R., Studies in Human Biology, Baltimore, 1924, 558.

de Ploucquet, W. G., Literatura Medica Digesta, Tubingen, 1809, IV, 12.

Power, E., \& Postan, M. M., English Trade in Fifteenth Century, London, 193.

Primerosius, J., Partes Duae de morbis puerorum, Rotterdam, 1659, 121.

Rogers, J. E. T., History of Agriculture and Prices in England, Oxford, 1866-1902.

Schanz, G., Englische Handelspolitik, Leipzig, 1881.

van Swieten, G. L. B., Commentaria in Hermanni Boerhaave Aphorismos, Lugd. Bat., 1772, V, 578.

Underwood, M., Treatise on the Diseases of Children, London, 1819, I, 391. 